\title{
Runon puheenomaisuudesta
}

Kiitämme puolestamme Vesa Haapalaa (Avain 1/2008) paneutuneesta arvostelusta, joka koskee oppikirjaa Lentävä hevonen. Välineitä runoanalyysiin (toim. Kainulainen, Kesonen \& Lummaa 2007). Huomiotamme kiinnitti ja ajatuksiamme kirvoitti Haapalan tapa priorisoida runon puhujan identiteetin ja puhetilanteen analyysia. Monitulkintaisuuden nimissä emme tee synteesiä näkemyksistämme, vaan seuraavassa ensin kantansa tuo esille Karoliina Lummaa ja toiseksi Siru Kainulainen.

\section{Runous ja vieraat elämänmuodot}

Käytän usein puhuja-termiä runon subjektiin viitatessani - en kuitenkaan siinä käsityksessä että runous olisi aina tai yksinomaan puhetta. Puheenomaisuus on mielestäni vain yksi runouden piirteistä. Esimerkiksi visuaaliset ja konkreettiset runot ovat usein tekstejä, joita on hankalaa, ellei mahdotonta, lähestyä puheena. Teemu Mannisen www.nokturno.org -sivustolla julkaistu "Cri-tic" saattaa olla kirjallisuuskritiikoiden toimintaa kommentoidessaan puheenomainen, mutta eikö tämän tekstiolion olemus ole myös ratkaisevan punkkimainen:

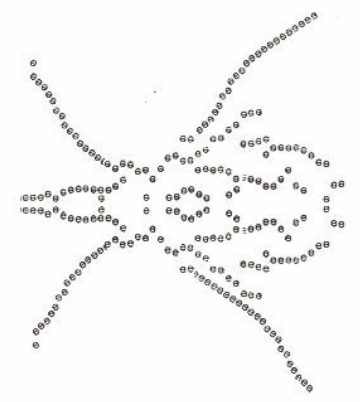

Tämä kirjaimista hämähäkkieläimen muotoon rakennettu tekstiolento tarjoaa ruumiinsa kriitikoiden ravinnoksi saaden samalla itse muotonsa ja elantonsa kirjallisuusinstituutiosta. "Cri-tic" on ei-inhimillistä elämää jäljittelevä tekstuaalinen ja institutionaalinen loinen.

Uskon, että runous voi luoda keinotekoista elämää ja kuvata vieraita elämänmuotoja. Tahdonkin ottaa puheenomaisuuteen kantaa ennen kaikkea ei-inhimillisen läsnäoloa koskevan kysymyksenasettelun kautta, koska se on itselleni niin tutkimuksessa kuin tutkimuksen ulkopuolella läheinen ja tärkeä. Lähtökohtani on se, että vaikka runous on aina inhimillisen tietoisuuden välittämää, tästä ei välttämättä seuraa se, että runous on inhimillistä puhetta. 
Ei-inhimillisen subjektiuden mahdollisuus on pysynyt ekokriittisen runoudentutkimuksen peruskysymyksenä 1980-luvun puolivälistä näihin päiviin asti. Ympäristötietoisen tai ekologisen runouden ominaispiirteenä ei koskaan ole pidetty luonnon puolesta puhuvaa inhimillistä ääntä vaan päinvastoin sellaisten kielellisten keinojen etsimistä, jotka vaientaisivat inhimillisen subjektin ja antaisivat tilaa ei-inhimillisen äänille. Yleensä tämä vaientaminen on tulkittu jonkinlaiseksi aporiaksi, jossa tauot, ristiriidat ja merkityksen kriisi avaavat tilaa ei-inhimilliselle (Scigaj 1999; Gilcrest 2002).

Viimeaikaisessa ekokriittisessä runoudentutkimuksessa ajatusta inhimillisen vaientamisesta on oikeutetusti myös kritisoitu (Morton 2007). Eivät eläinten äänet kuulu tyhjillä riveillä sen paremmin kuin täytetyilläkään. Ongelmana onkin omasta mielestäni juuri ajatus äänistä tai puheesta: miksi runon pitäisi aina olla puhetta, inhimillistä tai ei-inhimillistä?

Jos runous myönnetään inhimillisen alueelle kuuluvaksi, mutta sitä ei käsitetä kategorisesti puheeksi, runoudelle tulee mahdolliseksi etsiä vaihtoehtoisia perspektiivejä myös sellaisilta kokemuksen alueilta, jotka eivät ole tuttuja tai omia. Vieraat elämänmuodot tulevat runouden ja siten kielen alueelle, kommunikoitaviksi ja jaettaviksi (Gifford 1995). Tällöin ajatus puheenomaisuudesta runon lajiominaisuutena väistämättä problematisoituu.

Runouden suhde kieleen on samanaikaisesti loputtoman optimistinen ja väsymättömän kriittinen. Oman runouskäsitykseni rakentuu pitkälti juuri tämän kaksinaisen suhteen varaan. Runous kääntyy kohti maailmaa, inhimillistä ja ei-inhimillistä, mutta samanaikaisesti se kiertyy itseensä. Hurmaava esimerkki tästä liikkeestä on Eira Stenbergin "Runon materialismi" kokoelmasta Kapina huoneessa (1966). Tämä runon piirteitä luetteleva proosamuotoinen teksti päättyy sanoihin, jotka minän ehdollisuutta korostaessaan merkitsevät minulle paljon: ”Se seisoo kuin ainakin elämän kynnyksellä. Sen puolipuku on mielteiden yhdistys, kuten minä, oppisana ihmisen kokonaisuudesta, ykseydestä.” Elämän kynnyksellä seisoessaan runous pystyy pukeutumaan inhimilliseksi minäksi ja hänen puheekseen, mutta se on vain yksi vaihtoehto. Kynnykseltä on uskoakseni suunta myös vieraaseen, jopa ei-inhimilliseen elämään.

\section{Karoliina Lummaa}




\section{Runon rytmikäs ilmaisu}

Runo mielletään tutkimuksessa toisinaan puheen kaltaiseksi. Tähän osaltaan viittasi Vesa Haapala kirja-arvostelussaan. Lisäksi Haapala kirjoittaa lyriikan olevan erityinen laji muun kirjallisen kommunikoinnin joukossa. Piirre, joka puheenomaisuuteen usein vielä liitetään, on se, että nykyrunon rytmin oletetaan lähenevän, muistuttavan tai jäljittelevän puheen rytmiä.

Kuka runossa puhuu, on oivallinen analyyttinen kysymys, joka usein herää runon äärellä. Jos kuitenkin tyydytään hahmottamaan puhujan identiteettiä, saatetaan ohittaa runon tulkinnan monia mahdollisuuksia. Varsinkin opetustilanteissa olisi vaikea perustella, miksi - jos kyse kerran on puheesta ja puhujaidentiteetistä - runossa kuitenkin avautuu niin absurdeja tilanteita ja ristiriitaista toimintaa. Minkä takia rytmi ja muoto voivat korostua ylenpalttisesti tai runossa muuten toistellaan jotakin sanaa, asiaa tai muuta ainesta näennäisen perusteettomasti? Miksei runossa vain sanota suoraan se, mihin pyritän, on kysymys, jonka olen kuullut opiskelijoiden esittävän.

Entä jos runouden kieli onkin erityistä kieltä, joka ei redusoidu kommunikaatioksi? Ja entä kun runosta puuttuu poeettinen minä kokonaan? Entä jos asiakeskeinen päämäärä ei olekaan runossa olennaista? Rohkenen epäillä, että joidenkin runojen kohdalla on mahdotonta tai epärelevanttia keskittyä puhujan hahmoon, saati identiteettiin. Tällöin runon subjekti merkitsee jotakin muuta kuin inhimillistä puhetta tuottavaa hahmoa, henkilöä tai identiteettiä. Näin ajattelen olevan vaikkapa Henriikka Tavin Esim. Esa-teoksen (2007) kohdalla. Proosaruno on myös esimerkki siitä, että runo jo muodollaan kutsuu lukemaan runoa tekstinä, jolla on tietty muoto. Muotoa ei voikaan hahmottaa puheesta. Puhujaksi tai minäksi asettuminen voi sitä paitsi toisinaan olla mahdotonta, kuten näyttäisi olevan joidenkin Eila Kivikk'ahon runojen kohdalla. Runo ilmaisee silloin muilla kuin puheen keinoilla, esimerkiksi rytmisesti.

Lähtökohtana voikin olla se, että runo ilmaisee poeettista subjektia eikä minää, joka puhuu lukijalle. Näin avautuu tulkintamahdollisuuksia, joita ei voida saavuttaa, kun runo mielletään jonkun hahmon tai ihmisen puheeksi ja kommunikaatioksi. On siis kyse siitä, mikä ei runossa voi suoraan tulla kommunikaation piiriin ja mikä liittyy jäsenneltyä kielenkäyttöä häiriköimään ja elävöittämään pyrkivistä ajatusvirroista, kokemuksista, kuvitelmista, unista, unelmista, leikistä. Sanattoman ilmaisemisessa rytmin osuus on olennainen, runon vastaanottamisessa puolestaan affektiivisuuden ja kognitiivisuuden yhdistäminen. (Armstrong 2000, 2, 124; vrt. Kristeva 1975/1993.) Se merkitsee sitä, että runon analyysissa ja tulkinnassa ei pyritä muotoilemaan kohdetta uudelleen, vain "tietämään” sen (yhtä) merkitystä, merkitsijää tai merkittyä - tai identiteettikelpoista puhujaa.

Amittai F. Aviram (1994) kirjoittaa runon rytmistä inspiroivasti. Hänen mukaansa rytmin erityisyys runossa on jotakin, mikä tekee siitä lajityypillistä. Kirjoitetun rytmin 
toisto, säännönmukainen sännnöttömyys, joka koskee niin vapaarytmistä kuin mitallistakin runoa, ei purkaudu suoraan merkeiksi ja representaatioiksi. Se ei ole suoraan "käännettävissä". Aviram menee jopa niin pitkälle, että hän väittää runon oikeastaan olevan allegoria rytmistä/än, jota ei voi sanoin ilmaista sellaisenaan. Se on kielen materiaalisuutta. Runo voi näin ollen mahdollistaa pysähtymisen toisenlaisuuden äärellä sekä kielen materiaalisen ja kerroksisen aineksen havainnoinnin, mikä ei puhetta kuunneltaessa onnistu. Näin voi myös tarjoutua potentiaalia käsitellä asioita, jotka eivät ole suoraan kommunikoitavissa. Tällaiset asiat saattavat liittyä historiallisen ja sosiaalisen tilanteen hierarkiaan ja sen kritisoimisen mahdollisuuteen, joka ei purkaannu selvänä puheena. Rytmi tarjoaa tilaa kokea ja kuvitella jotakin muuta, mitä voisi kuvata affektiiviseksi tiedonannoksi.

Kielen materiaalisuus koskettaa reaalisti, vaikkei se kommunikoi puheena (vrt. Viikari 1998). Runo voi siten materialisoitua lukijalleen. Kielen materiaalisuutta voidaan ilmaista ja havainnoida aivan tietyllä tavalla kirjoitetussa tekstissä, joka poikkeaa olennaisesti puheesta (vrt. Derrida 1967/2003). Ehkä joissakin tapauksissa näin on erityisesti runon kohdalla. Miksi muuten monimutkaista kieltä, miten muuten niin monenlaista toistoainesta usein tiiviissä muodossa, mistä muuten se tenho ja lumo, ärsytys ja hämmennys, jonka runo kykenee saamaan aikaan?

\section{Siru Kainulainen}

\section{Lähteet}

armstrong, isobel 2000: The Radical Aesthetic. Massachusetts \& Oxford: Blackwell Publishers Ltd.

aviram, amittai F. I994: Telling Rhythm. Body and Meaning in Poetry. Michigan: University of Michigan Press.

DERRIDA, JACQUeS 1967/2003: Freud ja kirjoituksen näyttämö. Suom. Merja Hintsa. Platonin apteekki ja muita kirjoituksia. Helsinki: Gaudeamus.

GIFford, TERrY I995: Green Voices. Understanding Contemporary Nature Poetry. Manchester University Press, Manchester \& New York.

GILCREST, DAVID W. 2002: Greening the Lyre. Environmental Poetics and Ethics. Reno \& Las Vegas: University of Nevada Press.

KRISTEVA, JULIA I 975/I 993: Identiteetistä toiseen. Suom. Pia Sivenius. Puhuva subjekti. Tekstejä 1967-1993. Helsinki: Gaudeamus.

MORTON, TIMOTHY 2007: Ecology without Nature. Rethinking Environmental Aesthetics. Cambridge \& London: Harvard University Press. 
Scigaj, Leonard M. 1999: Sustainable Poetry. Four American Ecopoets. Kentucky: The University Press of Kentucky.

VIIKARI, AULI I 998: Carpe Diem. Lukijaan suuntautumisen strategiat lyriikassa. Sanan voima. Keskusteluja performatiivisuudesta. Toim. Lea Laitinen \& Lea Rojola. Helsinki: SKS. 